\title{
ЗМІСТ ТА СТРУКТУРА САМООСВІТНЬОЇ ДІЯЛЬНОСТІ СТУДЕНТІВ ВИЩИХ ТЕХНІЧНИХ НАВЧАЛЬНИХ ЗАКЛАДІВ
}

Квітка Т. В. Зміст та структура самоосвітньої діяльності студентів вищих технічних навчальних закладів.

У статті проаналізовано сутність понять «самостійна робота студентів» та «самоосвітня діяльність», з'ясовано різницю між ними. Надається оглядова характеристика складників структури самоосвітньої діяльності студентів ВТНЗ, яка може здійснюватися під час вивчення ними математичних дисциплін. Автор розглядає логіку організації самоосвітньої діяльності, надає характеристику структурно-орієнтованого, інформаційно-стимулювального та практико-творчого етапів самоосвіти з урахуванням дидактичних особливостей кожного 3 них.

Ключові слова:самостійна робота студентів, самоосвітня діяльність, структура самоосвітньої діяльності, етапи самоосвітньої діяльності.

Квитка Т. В. Содержание и структура самообразовательной деятельности студентов высших технических учебных заведений.

В статье проанализирована сущность понятий «самостоятельная работа студентов» и «самообразовательная деятельность», выявлена разница между ними. Предлагается обзорная характеристика составляющих структуры самообразовательной деятельности студентов ВТУЗ, которая может осуществляться при изучении ими математических дисциплин. Автор рассматривает логику организации самообразовательной деятельности, предлагает характеристику структурноориентированного, информационно-стимулирующего и практико-творческого этапов самообразования, предлагает методы самообразования студентов с учетом дидактических особенностей каждого из них.

Ключевые слова: самостоятельная работа студентов, самообразовательная деятельность, структура самообразовательной деятельности, этапы самообразовательной деятельности.

Kvitka T. V. The content and structure of self education students of technical schools.

In the article analyzed the essence of the concepts of «independent work of students» and "self-educational activities», revealed the difference between them. A sightseeing characteristic components of the structure of self-activity of students of higher technical education establishments, which may be carried out in the study of mathematical disciplines. The author examines the logic of self-organization activities, offers characteristic structurally oriented, information and practice- stimulating creative stages of self, suggests methods of self-educational students based on the characteristics of each of these stages.

Key words: independent work of students, self-educational activity, the structure of self-activity, stages of self-activity.

Тенденції модернізації освітньої системи України пов’язані 3 переоцінкою цінностей, завдань освіти та іiі результатів у контексті нових вимог і можливостей, що ставить перед людством XXI століття. Сучасне життя настільки динамічне, що, тільки постійно розвиваючись і тренуючи свій інтелект, людина здатна ефективно інтегруватися до світового культурного, економічного, інформаційного простору. Доцільно згадати висловлювання відомого інженера-винахідника та бізнесмена 
Г. Форда, який стверджував, що навіть відмінний професіонал, який не займається самоосвітою, не розширює свій світогляд, не здатний думати творчо і відповідати вимогам часу. Ідея необхідності самоосвіти не $\epsilon$ новою. Так, ще 1808 року в романіпритчі Й. Гете устами свого персонажа чітко окреслює проблему, яка не втратила актуальності і донині: «Усе ж таки погано, що зараз усьому не можна навчитися на все життя. Наші предки використовували знання, отримані в юності, ми ж вимушені перенавчатися кожні п'ять років, якщо ми не хочемо зовсім відстати від моди» [3, с. 274]. Однак зрозуміло, що навчатися протягом усього життя в навчальному закладі неможливо. Тому в цьому контексті слушною $є$ позиція Д. Писарева: «Хто дорожить життям думки, той знає, що справжньою освітою є тільки самоосвіта і що вона розпочинається тільки 3 тієї хвилини, коли людин а, попрощавшись назавжди 3 усіма школами, стає головною господаркою свого часу і своїх занять» [9, с. 127]. Це означає, що відповідальність за вдосконалення професійних знань, умінь і навичок несуть не тільки освітні заклади, але й сам фахівець, який у процесі навчання у ВНЗ повинен оволодіти широким спектром умінь і навичок самоосвіти. Ця проблема постає найбільш актуальною для студентів вищих технічних навчальних закладів, зважаючи, що наразі спостерігається прискорений розвиток науки, техніки, технологій: «Цей шлях має витоки у накопичених людством природничо-наукових та інженерних знаннях, які щорічно стрімко зростають. Так, у галузі радіоелектроніки сума накопичених знань подвоюється за 10-12 років (а 3 урахуванням суміжних взаємопроникних галузей за 5-7 років), швидкодія сучасних обчислювальних засобів - кожні 18 місяців. Є всі підстави вважати, що ця тенденція не тільки зберігатиметься, але й матиме додаткові імпульси для розвитку, поглиблення» [4, с. 15]. Ці обставини висувають перед вищою технічною школою проблему підготовки майбутніх фахівців до процесу «освіти протягом усього життя»- до самоосвіти, однією 3 необхідних умов розв'язання якої визначається ефективна організація самостійної роботи студентів (СРС). Починаючи 3 середини 90-х років минулого століття, окреслене перебуває в полі уваги багатьох педагогів (В. Буряк, О. Малихін, Т. Барановська, О. Коновал, Н. Саєнко, М. Солдатенко та ін.). Теоретичному осмисленню сутності самоосвітньої діяльності (СОД) сприяло розроблення теоретикометодичних засад самоосвіти (В. Ледньов, В. Попов, В. Турченко та ін.), концепції неперервної освіти (С. Вершловський, Н. Ничкало, С. Сисоєва, В. Тимошенко та ін.). Слід зазначити, що, на наш погляд, у науково-методичних джерелах не зовсім чітко окреслюється межа між дефініціями «самостійна робота», «самостійна навчальнопізнавальна діяльність», «самоосвіта», на що звертає увагу, наприклад, О. Власова [2, c. 203]. Поділяючи позицію дослідниці І. Косенкової [5, с. 17], ми також уважаємо, що самоосвіту майбутнього фахівця, як більш широке педагогічне явище, не можна ототожнювати 3 самостійною роботою тому, що самоосвіта $\epsilon$ цілеспрямованим добровільним удосконаленням особистості в пізнавальній та професійній діяльності за допомогою: 1) самостійної та 2) науково-дослідної роботи. Самостійну роботу, яка здійснюється студентом під керівництвом викладача, а в деяких випадках за його опосередкованої участі, ми пропонуємо розглядати як один із засобів та необхідний і обов'язковий елемент самоосвіти. Водночас, ураховуючи розмаїтість поглядів науковців і педагогів-практиків на сутність самоосвіти, метою статті визначаємо висвітлення змісту та структури самоосвітньої діяльності студентів з урахуванням особливостей навчального процесу у вищому технічному навчальному закладі (BTH3).

Теоретичний аналіз психолого-педагогічних та науково-методичних джерел [1; 
$5 ; 6 ; 10]$ дозволив зробити припущення, що в найбільш загальному вигляді структура самоосвітньої діяльності містить такі складники:

- цілепокладання на засадах осмислення цінності самоосвіти та позитивної мотивації до самоосвітньої діяльності;

- проектування змісту СОД;

- вибір форм, методів і засобів СОД;

- виконавські дії у процесі СОД;

- самоконтроль, самооцінка, рефлексія СОД.

Зазначимо, що особливістю навчального процесу у ВТНЗ є посилена увага до вивчення математичних дисциплін («Диференціальні рівняння», «Лінійна алгебра» тощо) $[7 ; 8]$. Тому у процесі науково-педагогічного пошуку ми сконцентрували свої дослідницькі інтереси на вивченні дидактичних можливостей цих дисциплін щодо формування умінь самоосвітньої діяльності. Ураховуючи вище зазначене, структуру самоосвітньої діяльності студента під час вивчення математичних дисциплін схематично зобразимо рисунком 1 .

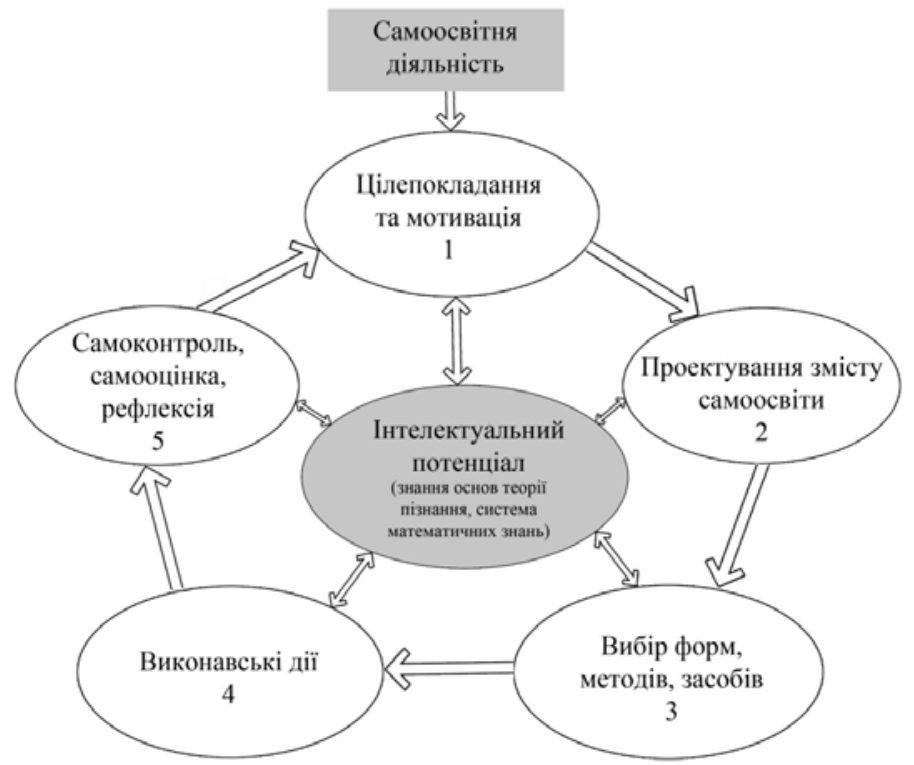

Рис. 1 Структура самоосвітньої діяльності студентів ВТНЗ

Запропонуємо оглядову характеристику компонентів самоосвітньої діяльності студентів ВТНЗ під час вивчення математичних дисциплін.

Підгрунтям забезпечення ефективної СОД постає інтелектуальний потенціал особистості як певний обсяг знань основ теорії пізнання, знань, умінь та навичок, набутих студентом у процесі оволодіння навчальною програмою 3 математики. Зростання інтелектуального потенціалу є водночас і результатом самоосвіти.

Важливим складником самоосвітньої діяльності визначаємо цілепокладання як прогнозування іiї результату на засадах ціннісних орієнтацій та позитивної мотивації як сукупності внутрішніх сил особистості, що спонукають до самоосвіти та надають ій певного змісту. Серед мотивів самоосвіти студента ВТНЗ найбільш значущими $є$ такі: 
- прагнення до постійного самовдосконалення;

- прагнення до самореалізації та самоствердження;

- прагнення до професійного зростання;

- прагнення до розширення знань (зокрема математичних);

- наявність пізнавальної зацікавленості;

- підвищення особистісного рейтингу успішності.

Змістом самоосвіти студентів ВТНЗ постає інформація, що як входить до навчальних програм з математичних дисциплін, так і виходить за їх межі. На відміну від самостійної роботи в самоосвітній діяльності студент як суб'єкт цієї діяльності повністю самостійно визначає зміст та обсяг матеріалу для засвоєння, форми, методи та засоби його опрацювання, термін роботи, самостійно обирає джерела інформації та місце роботи (бібліотека, домашнє робоче місце, аудиторія тощо).

Задля досягнення мети СОД необхідні виконавські дії: зовнішні, тобто спрямовані на зміну стану або властивостей предметів зовнішнього світу, і внутрішні, або розумові, які виконуються у внутрішньому плані в свідомості особистості. У процесі самоосвіти відбуваються процеси інтеріоризації (перехід від зовнішньої, матеріальної дії до внутрішньої) та екстеріоризації (процес переходу внутрішніх психічних актів у конкретні зовнішні дії), які перебувають у нерозривній єдності. Ураховуючи, що самоосвіта потребує оціночних суджень, вольових зусиль, ситуацій вибору мети СОД та iї здійснення, необхідними постають уміння самоаналізу, самоконтролю та рефлексії. Рефлексія студента як суб'єкта самоосвіти - це процес послідовних дій від аналізу ситуації, сумніву в оптимальності отриманих пізнавальних результатів до їх осмислення та пошуку шляхів поліпшення. Рефлексія як складник самоосвіти підвищує результативність СОД засобами зіставлення образів «Я - реальний професіонал» та «Я професіонал умайбутньому» через усвідомлення цінностей та мотивів самоосвіти.

Залучення до самоосвітньої діяльності передбачається здійснювати 3 перших днів навчання студентів технічних спеціальностей у ВТНЗ. Ураховуючи специфіку навчальних планів та програм цих вишів [7; 8], сприятливими умовами для організації СОД ми визначаємо процес вивчення математичних дисциплін. Логіка розгортання цього процесу хронологічно може бути такою.

Перший етап можна назвати структурно-орієнтованим. Розвиток цього етапу своїми коренями сягає моменту початку вивчення математичних дисциплін за програмами ВТНЗ та організації самостійної роботи студентів першого курсу. Психолого-педагогічною особливістю цього періоду визначаємо актуалізацію мотивів і визначення ціннісних сенсів самоосвіти, стимулювання позитивного ставлення до пізнавального та професійного саморозвитку під час опанування навчальної програми на аудиторних заняттях та у процесі СРС. Це можна пояснити тим, що більшості першокурсників притаманні близькі пізнавальні цілі, обмежені в основному, самостійною роботою під час підготовки до контрольної роботи, колоквіуму, заліку тощо. Способами самоосвіти є засвоєння інформації, окресленої навчальною програмою, з епізодичним зверненням до додаткової літератури. На спонукальноорієнтованому етапі під час вивчення математичних дисциплін рекомендованими $\epsilon$ види навчальної діяльності студентів, що містять елементи самоосвітньої діяльності: вивчення обов'язкової та додаткової літератури, текстів лекцій із їх самостійним допрацюванням, самостійне виконання завдань викладача із їх самоконтролем та самоаналізом, підготовка до семінарсько-практичних занять 3 вивченням додаткової літератури, добір задач підвищеної складності, їх розв'язання та колективний аналіз розв’язку у студентській аудиторії, підготовка до контрольних робіт та інших форм 
поточного контролю зі складанням опорних схем самостійно вивченого.

Основне завдання викладача на цьому етапі - зацікавити студентів у вивченні математичних дисциплін, стимулювати пізнавальні інтереси та спонукати студентів до систематичної самостійної пізнавальної діяльності 3 елементами самоосвіти. Позитивні особистісні зрушення суб'єктів навчальної діяльності на цьому етапі повинні знайти вираження в підвищенні мотивації до самоосвіти, можливо, ще не повністю усвідомленої та осмисленої, виникнення потреби в самостійному засвоєнні нових знань, опануванні нових методів опрацювання інформації, зокрема, елементів методів науково-аналітичної діяльності.

Другий етап залучення студентів ВТНЗ до самостійної діяльності визначаємо як інформаційно-стимулювальний. На цьому етапі більшої інтенсивності набуває формування умінь проектування змісту самоосвіти, умінь вибору оптимальних засобів досягнення іiі мети, удосконалення виконавських дій, удосконалення рефлексивно-корекційних умінь. Студент спрямовує пізнавальні зусилля на розв'язання конкретних практичних завдань.

Рекомендованими видами навчально-пізнавальної діяльності під час вивчення математичних дисциплін на цьому етапі підготовки до професійної самоосвіти постають більш складні завдання пошуково-аналітичної спрямованості: самостійний пошук, підбір та огляд джерел інформації за проблематикою навчальної програми та за іiі межами, складання анотацій, підготовка есе, рефератів оглядового характеру, циклу задач за темою, аналіз найновітніших наукових публікацій за темою, яка вивчається, підготовка до практикумів 3 математичних дисциплін 3 використанням комп'ютерних технологій. Завдання викладача математики на цьому етапіформування у студентів яскраво вираженого інтересу до самоосвіти в широкому розумінні цього феномену і до самоосвіти в галузі математики зокрема. Оптимальним результатом цього етапу має постати формування стійкого інтересу до самоосвітнього процесу, поглиблення і розширення знань з математики та теорії пізнання, пошук шляхів їх використання в майбутній професійно-технічній діяльності.

Третій етап можна позиціювати як практико-творчий, на якому має відбуватися об'єднання умінь самоосвітньої діяльності в систему з акцентуванням на розвиток творчих умінь самоконтролю, самооцінки навчальних досягнень, рефлексії набутого досвіду самоосвіти, прогнозування іiі індивідуальних траєкторій, пов'язаних із професійними перспективами та індивідуальними особливостями особистості. На цьому етапі у процесі вивчення математичних дисциплін має відбуватися відпрацювання нових способів пізнавальної діяльності: розв'язання проблемних завдань, завдань підвищеної складності, опрацювання теоретичного матеріалу, який виходить за межі навчальної програми, презентації накопичених у процесі самоосвіти знань та умінь у вигляді проектів, рефератів творчого характеру, опорних конспектів та структурно-логічних схем, карт математичних понять, добірки системи задач для розв'язання в аудиторії, обговорення їх розв'язків у проблемних групах, самостійний добір джерел інформації. Важливим завданням викладача в цей період $є$ залучення студентів до участі в наукових студентських гуртках, конференціях і семінарах, підготовці наукових публікацій, виконанні практичних завдань відповідно до кафедральних дослідницьких проектів. Дидактичні результати цього етапу полягають у підвищенні якості знань з математики, розгорнутій самооцінці, сформованих уміннях самоконтролю й рефлексіі, сформованих уміннях оптимального вибору змісту самоосвіти та цілепокладання.

Підсумовуючи викладене, наголосимо, що самоосвіту майбутнього фахівця не 
можна ототожнювати з самостійною роботою студентів. Це обгрунтовується тим, що самоосвіта $\epsilon$ цілеспрямованим добровільним удосконаленням особистості в пізнавальній та професійній царині за допомогою самостійної та науково-дослідної діяльності. Самостійна ж робота $є$ одним із засобів самоосвіти та їі необхідним елементом. Самоосвіта $є$ інтегративним процесом самовдосконалення особистості, складником іiі інтелектуального саморозвитку, завдяки якому формуються вміння самоосвітньої діяльності. У зв'язку 3 цим дослідження змісту системи вмінь самоосвітньої діяльності студентів ВТНЗ розглядаємо як вектор наших подальших наукових розвідок.

\section{Література}

1. Буряк В. Умови та засоби самоосвіти студентів / Володимир Буряк // Вища школа. - 2002. - № 6. - С. 18-36. 2. Власова О. І. Педагогічна психологія: [навч. посібник] / О. І. Власова. - К. : Либідь, 2005. - 400 с. З. Гете И. В. Собрание сочинений: [в 10 т.] / Гете И. В.; пер. с нем.; под общ. ред. А. Аннисста и Н. Вильмонта. - М. : Худож. лит., 1975, - Т. 6. - 478 с. 4. Зіньковський Ю. Креативність - фрактал сучасної парадигми вищої технічної освіти/Юрій Зіньковський, Георгій Мірських // Вища освіта України. - 2007. - С. 14-26. 5. Косенкова І. Створення умов для самоосвітньої діяльності вчителів у міжкурсовий період / І. Косенкова // Школа. - 2012. - № 11 (83). - С. 12-17. 6. Крутій К. Вплив чинників зовнішнього середовища та стратегії самоосвіти педагога дошкільного закладу, або Як провести SWOT- та PEST-аналіз / Катерина Крутій, Наталія Ганжа // Дошкільна освіта. - 2012. - № 2 (36). - С. 16-25. 7. Навчальна програма (робота) 3 дисципліни «Диференціальні рівняння» для студентів напряму підготовки 6.050702: Електромеханіка. - Кривий Ріг : ДВНЗ «Криворізький національний університет».2013. - 6 с. 8. Навчальна програма (робоча) 3 дисципліни «Лінійна алгебра» для студентів напряму підготовки 6.050702: Електромеханіка. - Кривий Ріг: ДВНЗ «Криворізький національний університет». - 2013. - 6 с. 9. Писарев Д. И.

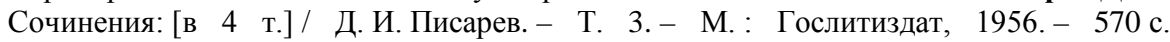
10. Малихін О. В. Організація самостійної навчальної діяльності студентів вищих педагогічних навчальних закладів: теоретико-методологічний аспект: [монографія]/ Олександр Володимирович Малихін. - Кривий Ріг : Видавничий дім, 2009. - 307 с.

Ірина Ланова

\section{ЗНАЧЕННЯ УКРАЇНСЬКОЇ ФАХОВОЇ ТЕРМІНОЛОГІЇ У ФОРМУВАННІ ПРОФЕСІЙНОЇ МОВЛЕННЕВОЇ КОМПЕТЕНТНОСТІ МАЙБУТНЬОГО СПЕЦАЛІСТА}

Ланова I. В. Значення української фахової термінології у формуванні професійної мовленнєвої компетентності майбутнього спеціаліста.

Висвітлюється завдання вищої школи на сучасному етапі підготовки майбутніх фахівців до опанування професійного мовлення - галузевої термінології. Розглянуто різні погляди щодо поняття «термін». Запропоновано різновиди вправ для ефективного засвоєння термінів та їх активного використання в українському фаховому мовленні.

Ключові слова: термін, галузева термінологія, термінолексика, українська фахова термінологія, професійна мовленнєва компетентність. 